\title{
Effect of troglitazone on radiation sensitivity in cervix cancer cells
}

\author{
Zhengzhe An, MS', Xianguang Liu, MD¹, Hyejin Song, MS1', Chihwan Choi, MD', \\ Won-Dong Kim, MD, PhD', Jae-Ran Yu, MD, PhD², Woo-Yoon Park, MD, PhD' \\ ${ }^{1}$ Department of Radiation Oncology, Chungbuk National University College of Medicine, Cheongju, \\ ${ }^{2}$ Department of Environmental and Tropical Medicine, Konkuk University College of Medicine, Chungju, Korea
}

\begin{abstract}
Purpose: Troglitazone (TRO) is a peroxisome proliferator-activated receptor $\gamma$ (PPAR $\gamma$ ) agonist. TRO has antiproliferative activity on many kinds of cancer cells via $\mathrm{G} 1$ arrest. TRO also increases $\mathrm{Cu}^{2+} / \mathrm{Zn}^{2+}$-superoxide dismutase (CUZnSOD) and catalase. Cell cycle, and SOD and catalase may affect on radiation sensitivity. We investigated the effect of TRO on radiation sensitivity in cancer cells in vitro.

Materials and Methods: Three human cervix cancer cell lines (HeLa, Me180, and SiHa) were used. The protein expressions of SOD and catalase, and catalase activities were measured at 2-10 $\mu \mathrm{M}$ of TRO for 24 hours. Cell cycle was evaluated with flow cytometry. Reactive oxygen species (ROS) was measured using $2^{\prime}, 7^{\prime}$-dichlorofluorescin diacetate. Cell survival by radiation was measured with clonogenic assay.

Results: By $5 \mu \mathrm{M}$ TRO for 24 hours, the mRNA, protein expression and activity of catalase were increased in all three cell lines. G0G1 phase cells were increased in HeLa and Me 180 by $5 \mu \mathrm{M}$ TRO for 24 hours, but those were not increased in SiHa. By pretreatment with $5 \mu \mathrm{M}$ TRO radiation sensitivity was increased in HeLa and Me180, but it was decreased in SiHa. In Me180, with $2 \mu \mathrm{M}$ TRO which increased catalase but not increased GO-G1 cells, radiosensitization was not observed. ROS produced by radiation was decreased with TRO.

Conclusion: TRO increases radiation sensitivity through GO-G1 arrest or decreases radiation sensitivity through catalasemediated ROS scavenging according to TRO dose or cell types. The change of radiation sensitivity by combined with TRO is not dependent on the PPAR $\gamma$ expression level.
\end{abstract}

Keywords: Troglitazone, Cervix cancer, Cell cycle, Catalase, Reactive oxygen species, Radiation sensitivity

\section{Introduction}

Peroxisome proliferator-activated receptor $\gamma$ (PPAR $\gamma$ ) is a critical transcription factor in the regulation of glucose and lipid metabolism [1]. Some of PPAR $\gamma$ agonists (rosiglitazone, pioglitazone) are currently used for the control of type II diabetes [2]. In addition, PPAR $\gamma$ agonist is of particular interest as a potential anticancer agent because of its effect on cellular differentiation, proliferation, and tumorigenesis $[3,4]$. Troglitazone (TRO) is a synthetic PPAR $\gamma$ agonist and has been studied extensively on its antiproliferative activities against many human cancer cells in vitro and in vivo, including those

Received 4 April 2012, Revised 26 April 2012, Accepted 10 May 2012.

Correspondence: Woo-Yoon Park, MD, PhD, Department of Radiation Oncology, Chungbuk National University College of Medicine, 410 Seongbong-ro, Cheongju 361-763, Korea. Tel: +82-43-269-6218, Fax: +82-43-269-6208, E-mail: wynpark@ chungbuk.ac.kr

(c) This is an Open Access article distributed under the terms of the Creative Commons Attribution Non-Commercial License (http://creativecommons.org/ licenses/by-nc/3.0/) which permits unrestricted non-commercial use, distribution, and reproduction in any medium, provided the original work is properly cited.

www.e-roj.org 
of prostate [5], breast [6], thyroid $[7,8]$, lung $[9,10]$, pituitary [11], colon [12] and liver [13]. This growth inhibition by TRO is linked to the $\mathrm{G} 1$ phase cell cycle arrest through the upregulation of the cyclin-dependent kinase inhibitors p21 and p27 [14-16] and/or repression of cyclin D1 expression $[17,18]$. The cells in $\mathrm{G} 1$ phase are relatively more radiosensitive than those in $\mathrm{S}$ phase, and this may cause radiosensitization. On the other hand, TRO shares a common structure with vitamin E which has a potent antioxidant property [19]. In addition, TRO can cause an induction of $\mathrm{Cu}^{2+} / \mathrm{Zn}^{2+}$-superoxide dismutase (CuZnSOD) $[20,21]$ and the activated receptor complexes of TRO can induce catalase through binding to its promoter region $[22,23]$. Both SOD and catalase may decrease radiation sensitivity via reactive oxygen species (ROS) scavenging. Although TRO was withdrawn from the market due to idiosyncratic hepatotoxicity [24], there is still much interest about the antitumor effect of TRO [25-27]. Most of antitumor effects was observed at relatively high concentrations (20$50 \mu \mathrm{M})$ of TRO, while the clinically achievable concentrations are around 2-5 $\mu \mathrm{M}[28,29]$. In addition, although combining low-dose PPAR $\gamma$ agonists with other drugs $[27,30]$ is highly effective, combining with radiation therapy has not been reported yet.

From the above we were interested in what will be the net result of combining low dose TRO and radiation by the contradictory effect of TRO; SOD or catalase induction and increased G1 cells. PPAR $\gamma$ agonist mediated growth inhibition is PPAR $\gamma$-dependent or -independent $[31,32]$. Therefore, we investigated the combining effects of TRO and radiation in cervix cancer cell lines with different level of PPAR $\gamma$ expression.

\section{Materials and Methods}

\section{Cells and culture conditions}

The cell lines were purchased from the Korean Cell Line Bank (Seoul, Korea). Cells were grown in Dulbecco's modified Eagle's medium (DMEM) or Roswell Park Memorial Institute (RPMI) containing 10\% fetal bovine serum (FBS) supplemented with $100 \mathrm{IU} / \mathrm{mL}$ penicillin, $100 \mathrm{\mu g} / \mathrm{mL}$ streptomycin. The cells were kept in a humidified atmosphere containing $5 \% \mathrm{CO}_{2}$ at $37^{\circ} \mathrm{C}$, and passaged by trypsinization. TRO was purchased from Cayman Chemical (Ann Arbor, MI, USA) and dissolved in dimethyl sulfoxide (DMSO) at a final concentration of $0.1 \%$ DMSO in the culture medium. All standard culture reagents were from Invitrogen (Carlsbad, CA, USA).

\section{Protein extraction for western blot and catalase activity assay}

Cell proteins was obtained by rinsing the cells with phosphatebuffered saline (PBS) pH 7.2 three times, scraping the cells from the culture flasks with a rubber policeman. The cells were washed with PBS by centrifugation two times. Pellets were kept frozen at $-80^{\circ} \mathrm{C}$ until use. At the time of analysis, the cell pellets were resuspended in one volume of $50 \mathrm{mM}$ potassium phosphate buffer ( $\mathrm{pH} 7.85$ ) and sonicated on ice 3 times for 10 seconds using a sonicator (Branson 1510R-DTH, Danbury, $\mathrm{CT}$, USA). Protein concentration was determined using the Bradford method using bovine serum albumin as a standard [33].

\section{Western blot analysis}

Proteins was denatured in 1 volume of sample buffer containing $62.5 \mathrm{mM}$ Tris- $\mathrm{HCl}(\mathrm{pH} \mathrm{6.8),} \mathrm{10 \%} \mathrm{glycerol,} \mathrm{2 \%}$ sodium dodecyl sulfate (SDS), $5 \% \beta$-mercaptoethanol (v/ v) and 2-3 drops of saturated bromophenol blue solution at $100^{\circ} \mathrm{C}$ for 3 minites. The proteins were separated in a $12.5 \%$ denaturing polyacrylamide gel by electrophoresis and then transferred onto nitrocellulose membranes at $100 \mathrm{~V}$ for 1 hour on ice. The blots were then blocked in 4\% dry milk in TweenTris buffered saline (TBS, $0.02 \mathrm{M}$ Tris buffer [pH 7.0] and 0.5\% Tween 20) at room temperature for 2 hours and incubated with primary antibody $(1: 1,000)$ in $\Pi B S$ at $4^{\circ} \mathrm{C}$ overnight. After washing three times with TBSS, 5 minutes each, the blots were incubated with secondary antibody $(1: 10,000)$. After washing three times, the blots were visualized using chemiluminescence (Intron Biotechnology, Seongnam, Korea). The antibodies for CuZnSOD, MnSOD, and catalase were purchased from AbFrontier (Seoul, Korea).

\section{Catalase activity assay}

Cells were treated with 2-10 $\mu \mathrm{M}$ of TRO for 24 hours. After getting cell pellets as described previously, protein concentration was determined using Bradford assay. Catalase activity was quantitated spectrophotometrically following the decomposition of $\mathrm{H}_{2} \mathrm{O}_{2}$ at $240 \mathrm{~nm}$ [34]. The catalase activity was expressed as $\mathrm{U} / \mathrm{mg}$ protein.

\section{RNA isolation and quantitative real-time polymerase chain reaction}

RNA was isolated from the cells using TRIzol reagent according to the manufacturer's protocol (Invitrogen, Carlsbad, CA, USA). cDNA synthesized using iscript reverse transcriptase 
reagent (Bio-Rad, Hercules, CA, USA) from $1 \mu \mathrm{g}$ of RNA. For real-time quantitative reverse transcription polymerase chain reaction (RT-PCR) for catalase, the following primers were used: forward 5'-GCCATTGCCACAGGAAAG-3', reverse 5'-GTCCTTGTGAGGCCAAACC-3'. The RT-PCR was performed in total $20 \mu \mathrm{L}$ of reaction solution containing diluted $\mathrm{CDNA}_{\text {, }}$ 20 pmol of each primer, $10 \mu \mathrm{L}$ of two-step SYBR green PCR (Finnzymes, Espoo, Finland) master mix and water. The thermal cycling parameters were $95^{\circ} \mathrm{C}$ for 10 minutes for Taq polymerase activation followed by 40 cycles of $95^{\circ} \mathrm{C}$ for 15 seconds, $60^{\circ} \mathrm{C}$ for 1 minute. The reactions were performed in triplicates in each experiment. The threshold cycles (Ct) were recorded from all the samples for both the target gene and the reference gene (glyceraldehyde 3-phosphate dehydrogenase, GAPDH). Melting curve analysis was done for each run. Relative gene expression of the target gene was calculated as $\Delta \Delta \mathrm{Ct}$, determined by subtracting the $\Delta \mathrm{Ct}$ of reference gene from the $\Delta \mathrm{Ct}$ of target gene. Experiment was repeated three times independently. The PCR machine and software used for this experiment is Rotor-Gene 6000 (Corbett Research Pty Ltd., Mortlake, NSW, Australia) and Rotor-Gene 6000 series software 1.7

\section{ROS measurement}

Intracellular production of ROS was measured using the fluorescent dye, 2',7'-dichlorodihydrofluorescein-diacetate (H2DCFDA) (Sigma, St. Louis, MO, USA) as described by Wan et al. [35]. Two days prior to experiments, cells were plated on $60 \mathrm{~mm}$ dishes. Cells were then exposed to $5 \mu \mathrm{M}$ of TRO for 24 hours. After drug treatment the cells were rinsed with PBS (no phenol red, $\mathrm{Ca} 2+$, or $\mathrm{Mg} 2+$ ) and incubated with 10 $\mu \mathrm{M}$ of $\mathrm{H}_{2} \mathrm{DCFDA}$ at $37^{\circ} \mathrm{C}$ for 10 minutes, and then irradiated using a linear accelerator (Mevatron, Siemens, CA, USA) at room temperature. The cells were detached with 0.25\% trypsin and $0.11 \%$ EDTA, washed and resuspended in cold PBS and placed on ice, and analyzed using a FACScan flow cytometer (FACS Calibur-S; Becton Dickinson, San Jose, CA, USA) (488 nm excitation, $530 \mathrm{~nm}$ emission). The mean geometric fluorescence intensity for 30,000 cells was analyzed for each sample using CellQuest Pro software (BD Biosciences, San Jose, CA, USA).

\section{Cell cycle analysis}

Cells were seeded in $60 \mathrm{~mm}$ culture plates. Next day, the cells were treated with 0-10 $\mu \mathrm{M}$ of TRO for 24 hours. Next, the cells were harvested by trypsinization and washed two times with PBS, then fixed overnight with $70 \%$ ethanol at $-20^{\circ} \mathrm{C}$. The cells were washed two times with PBS, resuspended with 1 $\mathrm{mL}$ of propidium iodide staining solution and then incubated for 30 minutes at $37^{\circ} \mathrm{C}$. Analysis of cell cycle distribution was performed using a flow cytometer (FACS Calibur-S; Becton Dickinson).

\section{Clonogenic assay}

Cells in growing phase were treated with TRO for 24 hours and irradiated. Irradiation was done using a linear accelerator (Mevatron, Siemens, CA, USA) with a dose rate of $3 \mathrm{~Gy} /$ minutes at room temperature. Varying number $(100-1,600)$ of cells for optimal colony counting was seeded in $60 \mathrm{~mm}$ dishes according to the presence or absence of TRO and radiation. After 6-7 days the cells were stained with $0.1 \%$ crystal violet solution and colonies which are composed of at least 50 cells, were counted.

\section{Statistics}

Results were expressed as mean \pm standard deviation (SD). All experiments were performed in triplicates. The two-tailed Student t-test was used to determine statistical significance of differences. A $p<0.05$ was considered statistically significant.

\section{Results}

\section{PPAR $\gamma$ expression in cervix cancer cell lines}

First, to know the expression pattern of PPAR $\gamma$ in cervix cancer cells the expression was screened with Western blot in three cervix cancer cell lines. PPAR $\gamma$ expression was high in Me180, and low in HeLa and SiHa (Fig. 1).

\section{SOD and catalase protein expression by TRO}

Both of CUZnSOD and MnSOD were not changed significantly

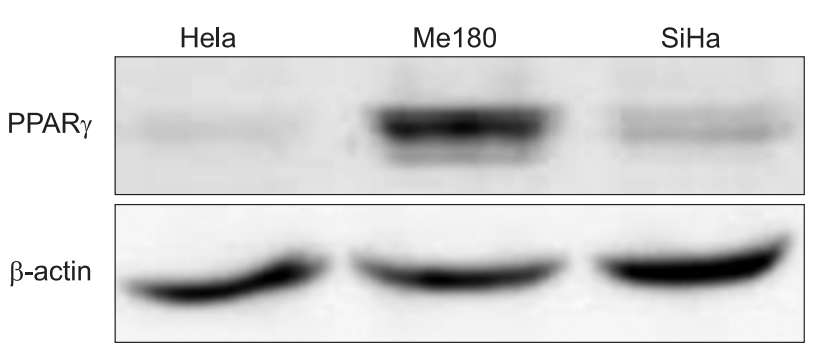

Fig. 1. Expression of Peroxisome proliferator-activated receptor $\gamma($ PPAR $\gamma)$ in cervix cancer cell lines. Expression of PPAR $\gamma$ was measured with immunoblots in three cervix cancer cell lines. This is a representative of three independent experiments. 

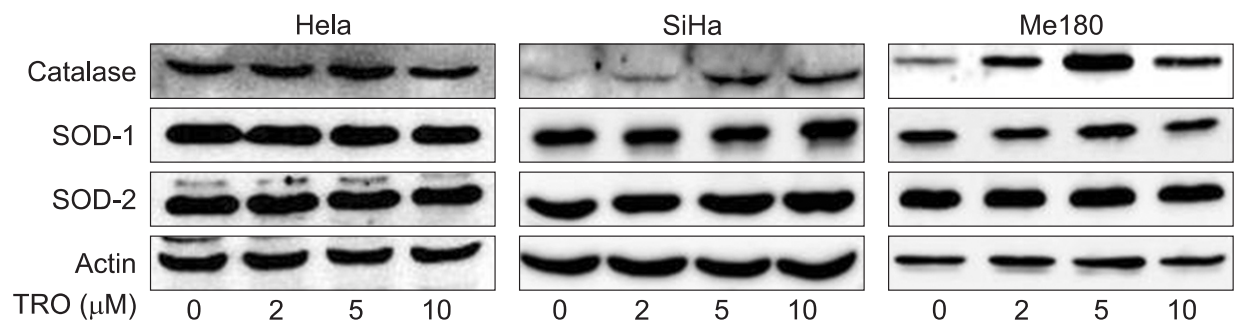

Fig. 2. The effect of troglitazone (TRO) on immunoblots of catalase, CuZn-superoxide dismutase (SOD) and MnSOD. Cells were exposed to $0,2,5$, and $10 \mu \mathrm{M}$ of TRO for 24 hours. This is a representative of three independent experiments.
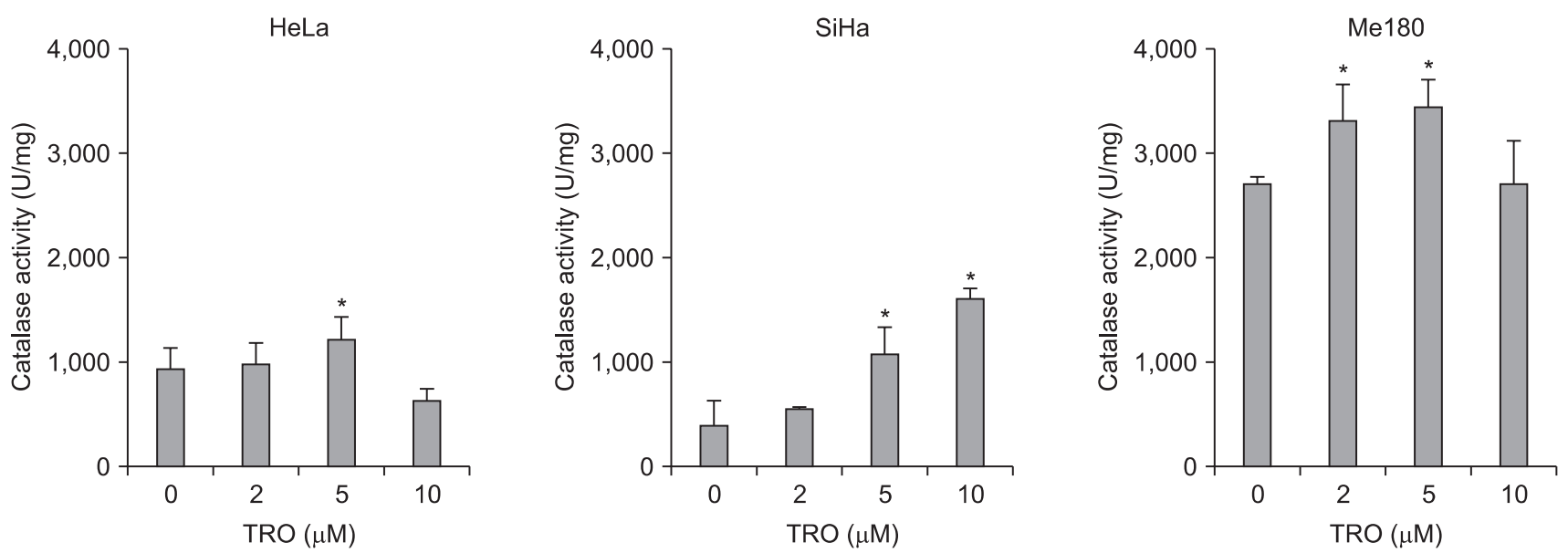

Fig. 3. Effect of troglitazone (TRO) on catalase activity. Catalase activity was measured after treatment with $0,2,5$, and $10 \mu \mathrm{M}$ of TRO for 24 hours. Activity is expressed as units per milligram of protein (U/mg) and means \pm standard deviation of four independent experiments. ${ }^{*} p<0.05$.

by TRO $(2,5$, and $10 \mu \mathrm{M}$ for 24 hours $)$ in all three cell lines. On the contrary, catalase increased according to the dose of TRO and reached maximum at $5 \mu \mathrm{M}$ (Fig. 2) in HeLa and Me180 cells. Increased catalase protein expression by TRO was much higher in Me180 (high PPARy expression) than HeLa cells.

\section{Catalase activity by TRO}

To confirm the correlation between the protein expression of catalase and its biological activity, catalase activity was measured. The activity was maximal at $5 \mu \mathrm{M}$ of TRO with 1.32 and 1.26 times higher than control in HeLa and Me180 cells, respectively (Fig. 3). The low catalase activity with $10 \mu \mathrm{M}$ of TRO seems to be due to cytotoxic effect of TRO in higher doses, because many cells were dead with $10 \mu \mathrm{M}$ of TRO. On the contrary, catalase activity continued to increase up to 10 $\mu \mathrm{M}$ of TRO in SiHa cells; 4.02 times higher than control. SiHa cells seem to be more resistant to high does TRO than the other cell lines. We confirmed catalase activity was suppressed by 3-amino-1, 2, 4-triazole (ATZ), a chemical catalase inhibitor,

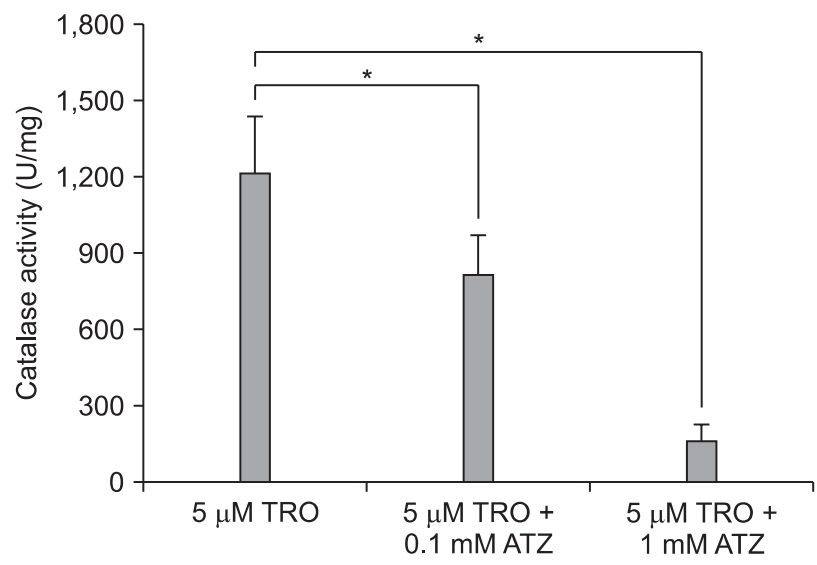

Fig. 4. Effect of aminotriazole (ATZ) on troglitazone (TRO)-induced catalase activity. HeLa dells were treated with $5 \mu \mathrm{M}$ of TRO, with or without ATZ $(0.1,1 \mathrm{mM})$ for 24 hours. The TRO-induced catalase activity diminished with the addition of ATZ, dose dependently. Activity is expressed as units per milligram of protein $(\mathrm{U} / \mathrm{mg})$, and means \pm standard deviation of four independent experiments. ${ }^{*} p$ $<0.05$. 

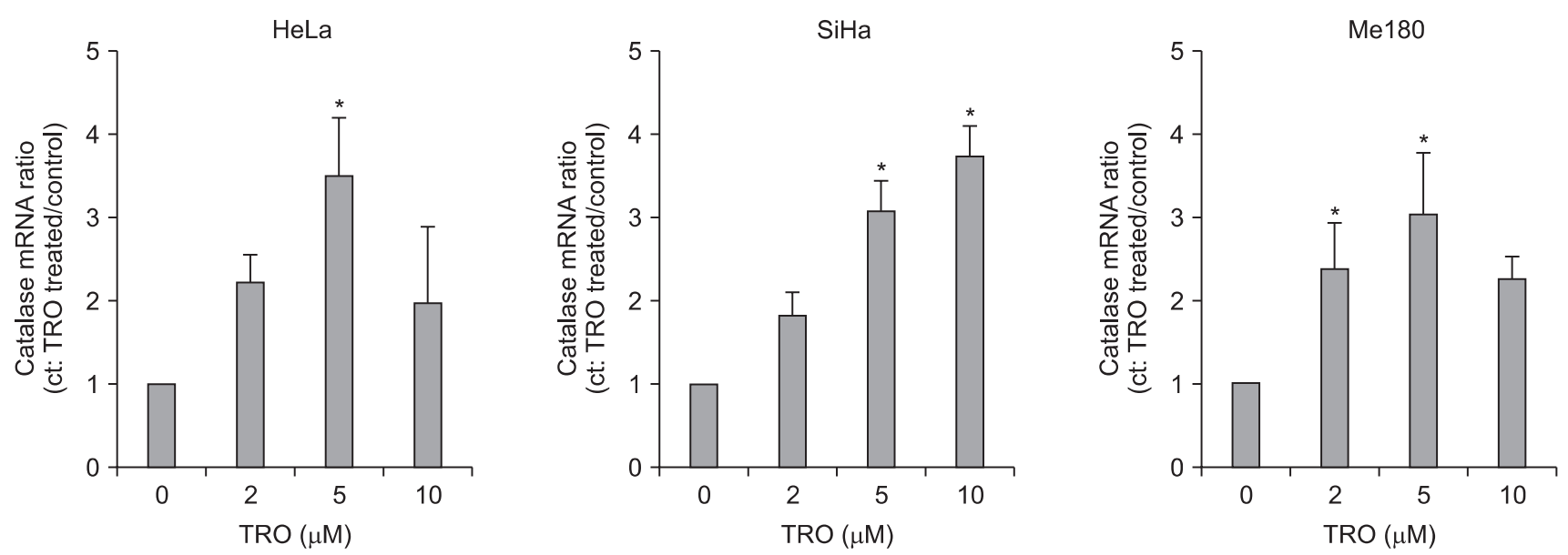

Fig. 5. The effect of troglitazone (TRO) on catalase mRNA expression. The cells were treated with $0,2,5$, and $10 \mu \mathrm{M}$ of TRO for 24 hours and catalase mRNA expression was measured using real time reverse transcription polymerase chain reaction. Data are means \pm standard deviation of three independent experiments. ${ }^{*} p<0.05$.
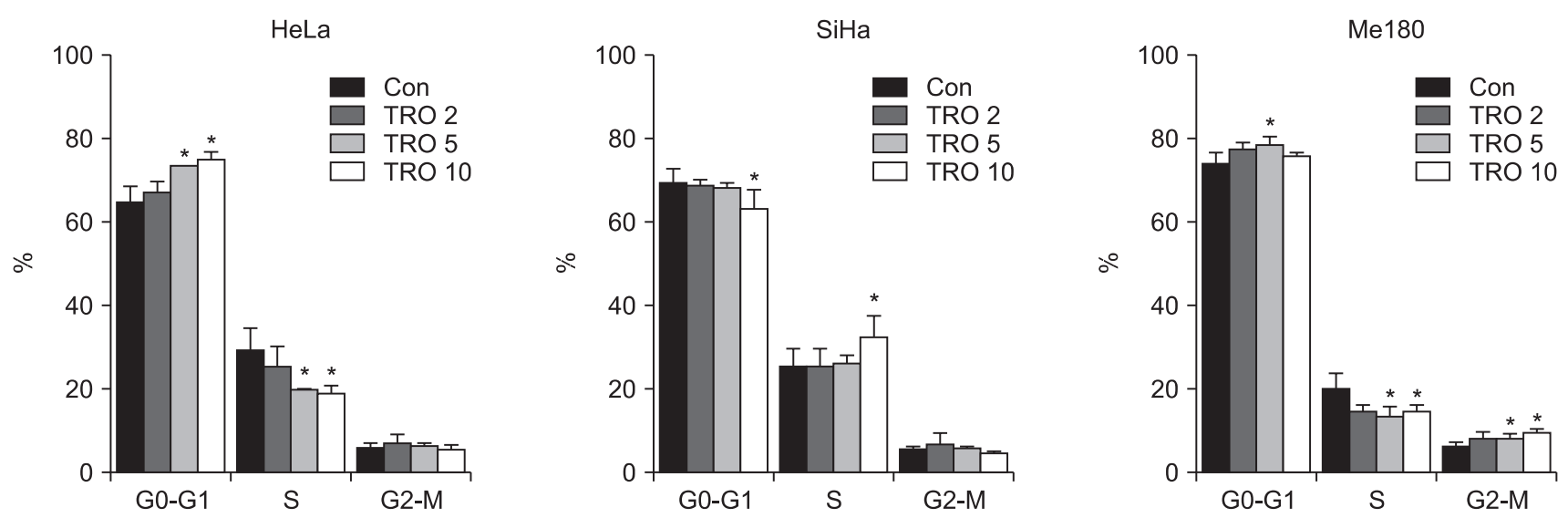

Fig. 6. The effect of troglitazone (TRO) on cell cycle distribution. The cells were treated with 0, 2, 5, and $10 \mu \mathrm{M}$ of TRO for 24 hours and cell cycle distribution was measured using flow cytometry. Data are means \pm standard deviation of three independent experiments. ${ }^{*} p<$ 0.05 .

dose dependently (0.1, 1 mM) (Fig. 4).

\section{Catalase mRNA expression by TRO}

To know whether increased catalase protein and activity come from induction of its mRNA, we measured mRNA expression using real time RT-PCR. As with the protein expression and activity, mRNA expression was maximal at $5 \mu \mathrm{M}$ of TRO in HeLa and Me180 cells (Fig. 5). In the other hand, catalase mRNA was increased even at $10 \mu \mathrm{M}$ in SiHa cells as with that of activity (Fig. 5).

\section{Cell cycle phase distribution change by TRO}

Cell cycle distribution is one of the important factors which govern radiation sensitivity. To know the cell cycle effect of TRO the cells were treated with TRO and cell cycle phase distribution was analyzed. In HeLa and Me180 the cells in G0G1 phase increased and those in S phase decreased with TRO treatment (Fig. 6). After 24 hours treated with $5 \mu \mathrm{M}$ TRO, the cells in G0-G1 phase increased from $64.5 \%$ to $73.5 \%$ and those in S phase decreased from $29.3 \%$ to $20.0 \%$ in HeLa cells. Such a cell cycle change pattern was observed in Me180 too: the cells in G0-G1 phase increased from 73.9\% to $78.6 \%$ and those in S phase decreased from 20.1\% to $13.2 \%$. However, such a cell cycle change was not observed in SiHa cells, that is, GO-G1 cells was decreased and S-phase cells were increased especially at $10 \mu \mathrm{M}$ TRO (Fig. 6). 
A

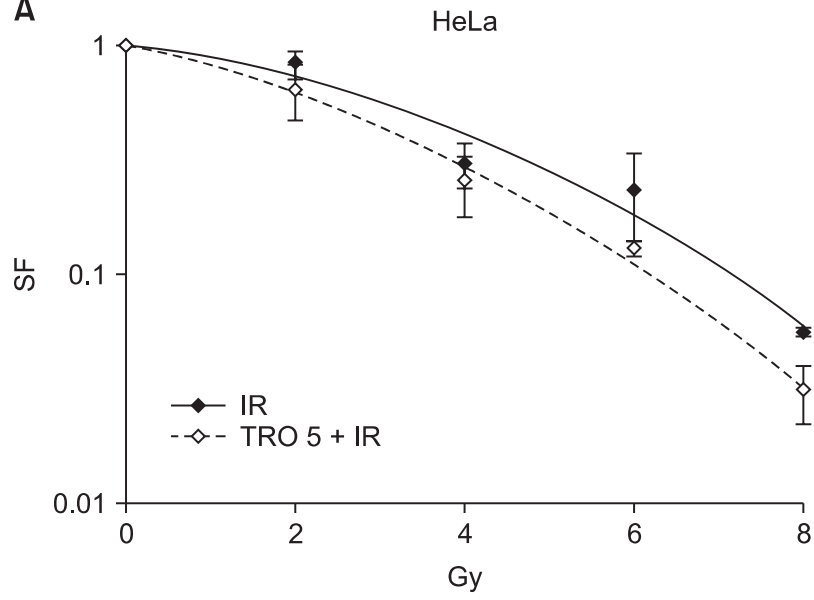

C

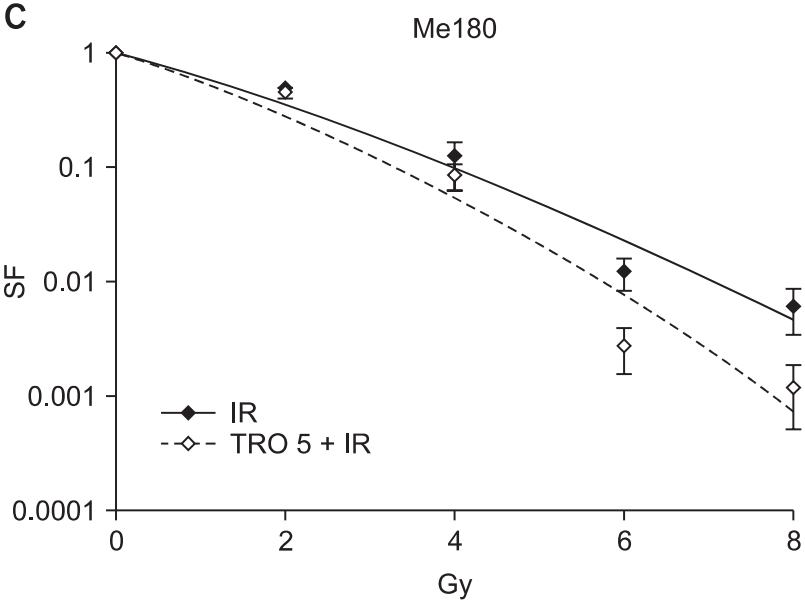

B

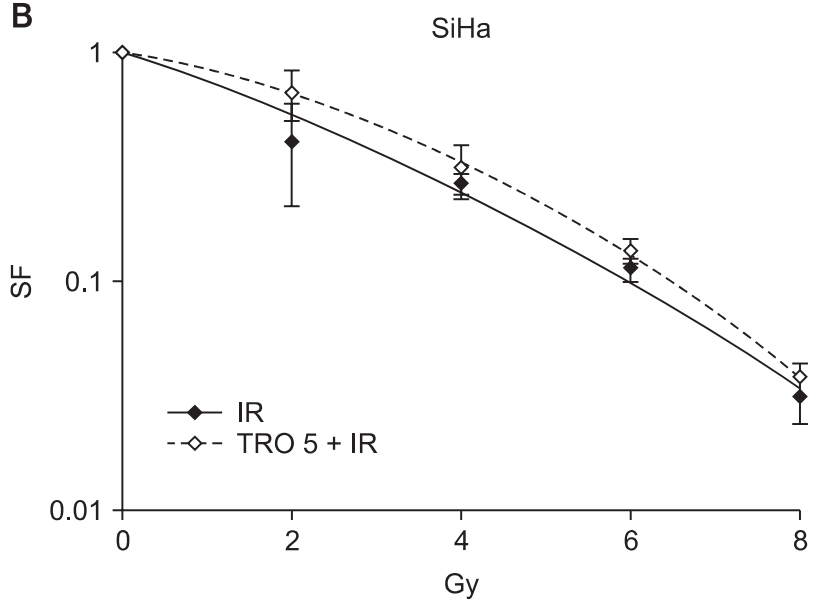

D

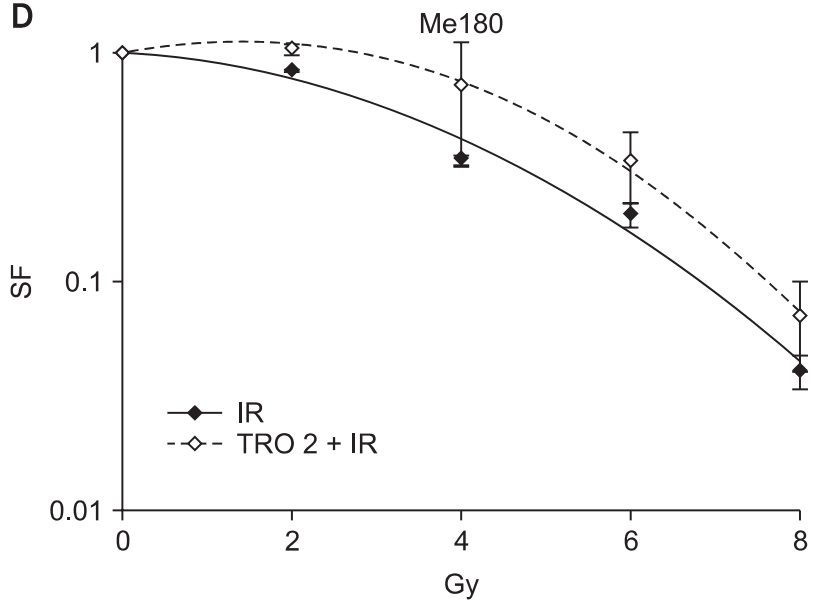

Fig. 7. Combined effect of troglitazone (TRO) and radiation on cell survival. Surviving fraction (SF) was measured by clonogenic assay after irradiation alone or pretreatment with $5 \mu \mathrm{M}$ of TRO in HeLa (A), SiHa (B), and Me180 (C). Also SF was measured after irradiation alone or pretreatment with $2 \mu \mathrm{M}$ of TRO in Me180 (D). Data are means \pm standard deviation of three independent experiments. ATZ, aminotriazole.

\section{Survival change by radiation with or without TRO}

To know the final outcome of radioprotective effect by catalase induction and radiosensitizing effect by cell cycle phase distribution clonogenic assay was done. The cells were treated with $5 \mu \mathrm{M}$ of TRO for 24 hours, which induces catalase and cells in G0-G1 phase maximally in HeLa and Me180 cells, and irradiated. Pretreatment with TRO increased radiation sensitivity in HeLa and Me180 cells (Fig. 7). However, it decreased radiation sensitivity in SiHa cells. These results indicate that cell cycle change by $5 \mu \mathrm{M}$ of TRO is more influential on radiation sensitivity than catalase induction in HeLa and Me180 cells. To differentiate the effect of cycle change from increased catalase activity, Me180 cells were treated with $2 \mu \mathrm{M}$ of TRO for 24 hours, which increased catalase activity but not G0-G1 cells, irradiated and clonogenic cell survival was measured. With $2 \mu \mathrm{M}$ of TRO radioprotective effect was observed (Fig. 7).

\section{ROS change by radiation with or without TRO}

To confirm TRO-induced catalase contributes to scavenge radiation-produced ROS and gives rise to radioprotective effect, HeLa cells were treated with 4 Gy with or without 5 $\mu \mathrm{M}$ of TRO and the change of ROS was measured. ROS was decreased with TRO. ROS was increased by irradiation and it was decreased in the cells pretreated with TRO (Fig. 8). With the addition of ATZ ROS was increased compared with TRO alone (Fig. 8). As shown in Fig. 4 catalase was decreased with the addition of ATZ. This indicates that catalase induced by TRO contributes to scavenge of ROS produced by radiation. 
A

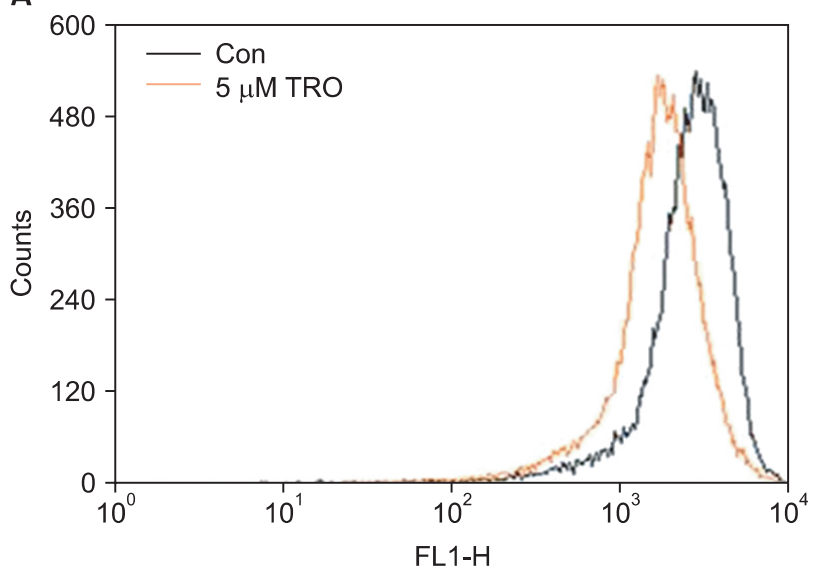

B

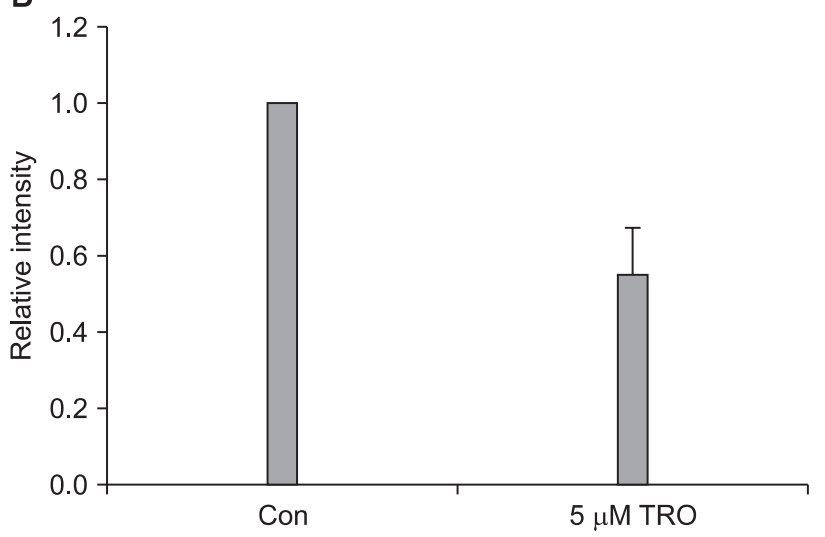

C

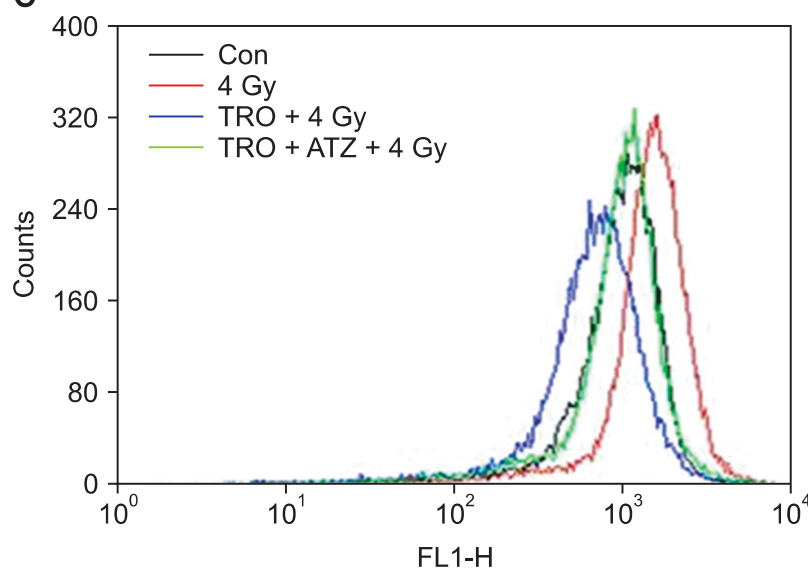

D

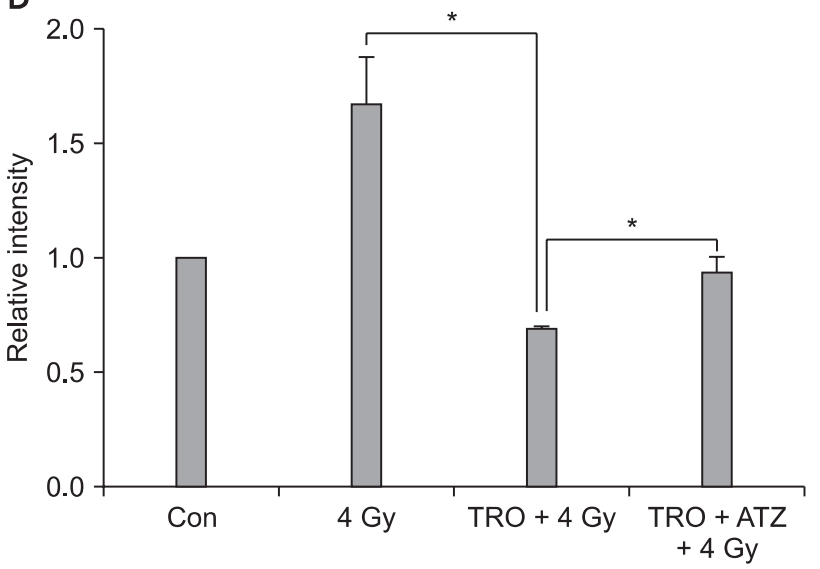

Fig. 8. The effect of troglitazone (TRO) on intracellular reactive oxygen species evel. HeLa cells were treated with $5 \mu \mathrm{M}$ of TRO alone (A). HeLa cells were treated with $5 \mu \mathrm{M}$ of TRO and catalase inhibitor-aminotriazole (ATZ) for 24 hours, and same volume of dimethyl sulfoxide was added to control. Next, cells were irradiated with $4 \mathrm{~Gy}$ (C). Distribution of ROS production was measured by dichlorofluorescein assay as described in the materials and methods. X-axis represents fluorescence, Y-axis represents cell number. (B) and (D) show relative intensity of fluorescence. Data are expressed as the ratio of control value and means \pm standard deviation of three independent experiments. ${ }^{*} p<0.05$.

\section{Discussion and Conclusion}

In this study we showed TRO increases radiation sensitivity through $\mathrm{G} 0-\mathrm{G} 1$ arrest or decreases radiation sensitivity through catalase-mediated ROS scavenging effect according to TRO dose or cell types in cervix cancer cell lines.

The PPAR responsive element (PPRE) was identified in the rat catalase promoter region and PPAR $\gamma$ agonists (rosiglitazone, ciglitazone) increase catalase mRNA and activity [22]. Conceptually, it is highly probable that TRO, as a member of PPAR $\gamma$ agonist, also induces catalase by binding to PPRE in the catalase promoter. However, there was no report on catalase induction by TRO yet and this is the first paper verifying catalase induction by TRO. TRO increased catalase mRNA, protein and activity in all three cervix cancer cell lines tested in this study regardless of basal level of PPAR $\gamma$ expression. A chemical inhibitor of catalase, ATZ, reduced catalase activity and decreased ROS scavenging effect of TRO. It can be postulated that the increased catalase plays a major role in the ROS scavenging effect of TRO. TRO has been expected to have an antioxidant activity from the viewpoint of its chemical structure. TRO has a chromane moiety similar to $\alpha$-tocopherol, whose antioxidant activity relies on the effective donation of hydrogen from the hydroxyl group of the chromane ring to reactive radicals $[19,36]$. The antioxidant activity of TRO has been demonstrated in many studies. TRO inhibits lipid peroxidation of low-density lipoprotein (LDL) $[37,38]$, and inhibits ROS generation in both of polymorphonuclear 
leukocytes (PMNLs) and mononuclear cells (MNCs), results in inhibition of lipid peroxidation in the obese [39]. However, most previous studies have focused on the structure-based antioxidant activity of TRO. Our study revealed that antioxidant activity of TRO come from not only chemical structure but also catalase induction. The antioxidant activity of TRO is dose dependent. That is, in higher dose (usually over $20 \mu \mathrm{M}$ ) TRO has a prooxidant activity and causes antiproliferation and cell death $[19,40]$. Twenty $\mu \mathrm{M}$ is much higher than that of clinically achievable concentration. If a patient takes 400 $\mathrm{mg} /$ day and $600 \mathrm{mg} /$ day the maximum plasma concentration of TRO was reported as $3.6 \mu \mathrm{M}$ and $6.3 \mu \mathrm{M}$, respectively [41]. With such a low concentration, cytocidal effect of TRO is negligible and combination with other agents has shown synergistic effect $[27,30]$. Radiation therapy is one of the most important modalities for cancer treatment. TRO induces GO-G1 arrest and catalase and those two are important factors which may determine radiation sensitivity. About two thirds of the biologic effect by $\mathrm{X}$-rays is caused by indirect action, which is mediated by free radicals produced from water. Catalase converts $\mathrm{H}_{2} \mathrm{O}_{2}$ to water and $\mathrm{O}_{2}$. In this study, catalase-mediated radioprotective effect was overcome by cell cycle-mediated (G0-G1 arrest) radiosensitizing effect by $5 \mu \mathrm{M}$ of TRO for 24 hours in HeLa and Me180 cells. With $2 \mu \mathrm{M}$ of TRO, which increased catalase but not G0-G1 cells, radiation sensitivity was decreased. In Me190 cells, catalase activity was increased significantly with $2 \mu \mathrm{M}$ of TRO compared with other cell lines.

SOD is one of the important enzymes which remove free radicals. TRO has been reported to induce CuZnSOD $[20,21]$. However, SOD proteins were not increased in all three cell lines tested in this study. This suggests that the induction of antioxidant enzymes, such as SOD and catalase by TRO is dependent on cell lines and cell types.

TRO is attractive as a possible anticancer drug. However, its antiproliferative effect has been studied usually with high doses (over $20 \mu \mathrm{M}$ ). Due to its heptotoxicity low dose of TRO combined with other modalities can be suggested. However, its catalase induction and cell cycle change can affect on the effect of other modalities. Therefore, on using TRO combined with other modalities, the factors which might affect on the effect of others have to be considered.

\section{Conflict of Interest}

No potential conflict of interest relevant to this article was reported.

\section{Acknowledgments}

This work was supported by Chungbuk National University Grant 2011.

\section{References}

1. Rosen ED, Sarraf $P$, Troy $A E$, et al. PPAR gamma is required for the differentiation of adipose tissue in vivo and in vitro. Mol Cell 1999;4:611-7.

2. Saltiel AR, Olefsky JM. Thiazolidinediones in the treatment of insulin resistance and type II diabetes. Diabetes 1996;45:16619

3. Michalik L, Desvergne B, Wahli W. Peroxisome-proliferatoractivated receptors and cancers: complex stories. Nat Rev Cancer 2004;4:61-70.

4. Wang $T, X u J, Y u X$, Yang $R$, Han ZC. Peroxisome proliferatoractivated receptor gamma in malignant diseases. Crit Rev Oncol Hematol 2006;58:1-14.

5. Kubota T, Koshizuka K, Williamson EA, et al. Ligand for peroxisome proliferator-activated receptor gamma (troglitazone) has potent antitumor effect against human prostate cancer both in vitro and in vivo. Cancer Res 1998;58:3344-52.

6. Yin F, Wakino S, Liu Z, et al. Troglitazone inhibits growth of MCF-7 breast carcinoma cells by targeting $\mathrm{G} 1$ cell cycle regulators. Biochem Biophys Res Commun 2001;286:916-22.

7. Ohta K, Endo T, Haraguchi K, Hershman JM, Onaya T. Ligands for peroxisome proliferator-activated receptor gamma inhibit growth and induce apoptosis of human papillary thyroid carcinoma cells. J Clin Endocrinol Metab 2001;86:2170-7.

8. Park JW, Zarnegar R, Kanauchi H, et al. Troglitazone, the peroxisome proliferator-activated receptor-gamma agonist, induces antiproliferation and redifferentiation in human thyroid cancer cell lines. Thyroid 2005;15:222-31.

9. Han S, Sidell N, Fisher PB, Roman J. Up-regulation of p21 gene expression by peroxisome proliferator-activated receptor gamma in human lung carcinoma cells. Clin Cancer Res 2004;10:1911-9.

10. Li M, Lee TW, Mok TS, Warner TD, Yim AP, Chen GG. Activation of peroxisome proliferator-activated receptor-gamma by troglitazone (TGZ) inhibits human lung cell growth. J Cell Biochem 2005;96:760-74.

11. Heaney AP, Fernando M, Melmed S. PPAR-gamma receptor ligands: novel therapy for pituitary adenomas. J Clin Invest 2003;111:1381-8.

12. Kato M, Kusumi T, Tsuchida S, Tanaka M, Sasaki M, Kudo H. Induction of differentiation and peroxisome proliferatoractivated receptor gamma expression in colon cancer cell lines 
by troglitazone. J Cancer Res Clin Oncol 2004;130:73-9.

13. Yu J, Qiao L, Zimmermann L, et al. Troglitazone inhibits tumor growth in hepatocellular carcinoma in vitro and in vivo. Hepatology 2006;43:134-43.

14. Koga $H$, Sakisaka $S$, Harada $M$, et al. Involvement of p21(WAF1/ Cip1), p27(Kip1), and p18(INK4c) in troglitazone-induced cell-cycle arrest in human hepatoma cell lines. Hepatology 2001;33:1087-97.

15. Yoshizawa K, Cioca DP, Kawa S, Tanaka E, Kiyosawa K. Peroxisome proliferator-activated receptor gamma ligand troglitazone induces cell cycle arrest and apoptosis of hepatocellular carcinoma cell lines. Cancer 2002;95:2243-51.

16. Bae MA, Rhee $H$, Song BJ. Troglitazone but not rosiglitazone induces $\mathrm{G} 1$ cell cycle arrest and apoptosis in human and rat hepatoma cell lines. Toxicol Lett 2003;139:67-75.

17. Wang C, Pattabiraman N, Zhou JN, et al. Cyclin D1 repression of peroxisome proliferator-activated receptor gamma expression and transactivation. Mol Cell Biol 2003;23:615973.

18. Huang JW, Shiau CW, Yang YT, et al. Peroxisome proliferatoractivated receptor gamma-independent ablation of cyclin D1 by thiazolidinediones and their derivatives in breast cancer cells. Mol Pharmacol 2005;67:1342-8.

19. Tafazoli S, Wright JS, O'Brien PJ. Prooxidant and antioxidant activity of vitamin $E$ analogues and troglitazone. Chem Res Toxicol 2005;18:1567-74.

20. Inoue I, Goto $S$, Matsunaga T, et al. The ligands/activators for peroxisome proliferator-activated receptor alpha (PPARalpha) and PPARgamma increase Cu2+,Zn2+-superoxide dismutase and decrease $\mathrm{p} 22$ phox message expressions in primary endothelial cells. Metabolism 2001;50:3-11.

21. Heo KS, Kim DU, Ryoo S, et al. PPARgamma activation abolishes LDL-induced proliferation of human aortic smooth muscle cells via SOD-mediated down-regulation of superoxide. Biochem Biophys Res Commun 2007;359:1017-23.

22. Girnun GD, Domann FE, Moore SA, Robbins ME. Identification of a functional peroxisome proliferator-activated receptor response element in the rat catalase promoter. Mol Endocrinol 2002;16:2793-801.

23. Okuno $Y$, Matsuda $M$, Kobayashi $H$, et al. Adipose expression of catalase is regulated via a novel remote PPARgammaresponsive region. Biochem Biophys Res Commun 2008;366: 698-704.

24. Graham DJ, Green L, Senior JR, Nourjah P. Troglitazoneinduced liver failure: a case study. Am J Med 2003;114:299306.

25. Coras $R$, Holsken $A$, Seufert $S$, et al. The peroxisome proliferator-activated receptor-gamma agonist troglitazone inhibits transforming growth factor-beta-mediated glioma cell migration and brain invasion. Mol Cancer Ther 2007;6:1745-54.
26. Weng JR, Chen CY, Pinzone JJ, Ringel MD, Chen CS. Beyond peroxisome proliferator-activated receptor gamma signaling: the multi-facets of the antitumor effect of thiazolidinediones. Endocr Relat Cancer 2006;13:401-13.

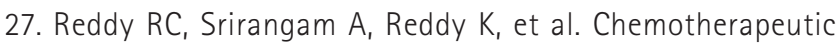
drugs induce PPAR-gamma expression and show sequencespecific synergy with PPAR-gamma ligands in inhibition of non-small cell lung cancer. Neoplasia 2008;10:597-603.

28. Welbourne T, Su G, Coates G, Routh R, McCarthy K, Battarbee $\mathrm{H}$. Troglitazone induces a cellular acidosis by inhibiting acid extrusion in cultured rat mesangial cells. Am J Physiol Regul Integr Comp Physiol 2002;282:R1600-7.

29. Xu Y, Lu L, Greyson C, et al. Deleterious effects of acute treatment with a peroxisome proliferator-activated receptorgamma activator in myocardial ischemia and reperfusion in pigs. Diabetes 2003;52:1187-94.

30. Yao CJ, Lai GM, Chan CF, Cheng AL, Yang YY, Chuang SE. Dramatic synergistic anticancer effect of clinically achievable doses of lovastatin and troglitazone. Int J Cancer 2006;118:773-9.

31. Turturro F, Friday E, Fowler R, Surie D, Welbourne T. Troglitazone acts on cellular pH and DNA synthesis through a peroxisome proliferator-activated receptor gamma-independent mechanism in breast cancer-derived cell lines. Clin Cancer Res 2004;10:7022-30.

32. Chaffer $C L$, Thomas DM, Thompson EW, Williams ED. PPARgamma-independent induction of growth arrest and apoptosis in prostate and bladder carcinoma. BMC Cancer 2006;6:53.

33. Bradford MM. A rapid and sensitive method for the quantitation of microgram quantities of protein utilizing the principle of protein-dye binding. Anal Biochem 1976;72:248-54.

34. Aebi H. Catalase in vitro. Methods Enzymol 1984;105:121-6.

35. Wan XS, Zhou Z, Ware JH, Kennedy AR. Standardization of a fluorometric assay for measuring oxidative stress in irradiated cells. Radiat Res 2005;163:232-40.

36. Yoshioka T, Fujita $T$, Kanai $T$, et al. Studies on hindered phenols and analogues. 1. Hypolipidemic and hypoglycemic agents with ability to inhibit lipid peroxidation. J Med Chem 1989;32:421-8.

37. Noguchi N, Sakai $H$, Kato $Y$, et al. Inhibition of oxidation of low density lipoprotein by troglitazone. Atherosclerosis 1996;123:227-34.

38. Crawford RS, Mudaliar SR, Henry RR, Chait A. Inhibition of $\mathrm{LDL}$ oxidation in vitro but not ex vivo by troglitazone. Diabetes 1999;48:783-90.

39. Garg R, Kumbkarni Y, Aljada A, et al. Troglitazone reduces reactive oxygen species generation by leukocytes and lipid peroxidation and improves flow-mediated vasodilatation in obese subjects. Hypertension 2000;36:430-5. 
40. Narayanan PK, Hart T, Elcock F, et al. Troglitazone-induced intracellular oxidative stress in rat hepatoma cells: a flow cytometric assessment. Cytometry A 2003;52:28-35.
41. Loi CM, Young M, Randinitis E, Vassos A, Koup JR. Clinical pharmacokinetics of troglitazone. Clin Pharmacokinet 1999;37:91-104. 